\title{
A Behavioral Learning Theory Public Health Promotion and Education Campaign Plan for COVID-19
}

\section{Lisa Marie Portugal}

American College of Education

Corresponding Author: Dr. Lisa Marie Portugal, American College of Education.

Received date: July 31, 2020; Accepted date: September 12, 2020; Published date: September 16,2020

Citation: Portugal L M (2020) A Behavioral Learning Theory Public Health Promotion and Education Campaign Plan for COVID-19.J General medicine and Clinical Practice. 3(2) DOI: 10.31579/2639-4162/028

Copyright: (02020. Lisa Marie Portugal This is an open-access article distributed under the terms of the Creative Commons Attribution License, which permits unrestricted use, distribution, and reproduction in any medium, provided the original author and source are credited.

\begin{abstract}
The article includes a COVID-19 public health promotion and education campaign plan to prompt change by applying major behavioral change principles and procedures. Best practices research to motivate, support, and sustain health behavior change includes the application of Behavioral Learning Theory when educating the public regarding COVID-19 health challenges. Topics evaluated include: (1) Behavioral Learning Theory, (2) 6-month timeline for accomplishing three COVID-19 public health communication objectives, and (3) SWOT analysis.

Key words: COVID-19, COVID, Novel Corona Virus, Behavioral Learning Theory, public health, promotion and education, public relations campaign, advertising campaign, communication strategies, health communications, behavioral objectives, health objectives, health behaviors, naturopathy, holistic healing, natural medicine, alternative medicine, Traditional Chinese Medicine(TCM), Western Herbalism, immunity.
\end{abstract}

\section{Introduction}

Public health can be improved through better communication that can involve digital social media tools, social marketing, and innovative communication strategies to find more and new creative methods to encourage lasting behavioral changes resulting in improved health (Giovanelli, et al., 2020; LaMorte, 2016; Simpson, 2015). Stakeholders and cooperating partnerships such as holistic natural medicine practitioners, providers, and auxiliary healthcare services can aid in a media and public relations COVID-19 health campaign by supporting the holistic healing agenda and collaborating with educational efforts. Furthermore, program evaluation can be measured with the aid of cooperating partnerships.

\section{Behavioral Learning Theory Applied}

A COVID-19 health promotion and education campaign can address three challenges concerning public health such as:

1. A lack of public awareness regarding a holistic healing perspective for COVID-19 treatment;

2. An educational need regarding how the public can be more proactive in holistic natural medicine health maintenance;

3. A lack of comprehensive knowledge regarding how to build the body's immunity in a holistic natural medicine manner. A lack of comprehensive knowledge regarding cardiovascular disease, cholesterol, blood pressure, diet, exercise, and how these variables bear upon poor health conditions (CDC, 2016).

The positive influence Behaviorism theory can have on a holistic public health promotion and education campaign for COVID-19 can be to educate the public regarding health problems associated with low information or lack of substantive health information (LaMorte, 2016; Simpson, 2015).

A public health promotion and education campaign can use Behaviorism theory to educate the public regarding negative diet habits versus healthy diet choices and associated effects on health and wellness (Giovanelli, Ozer, \& Dahl, 2020; LaMorte, 2016; Simpson, 2015). Research, statistics, facts, and effects on health related to poor lifestyle choices can be shared through a comprehensive public education and media campaign (Giovanelli, et al., 2020). A Behaviorism theory health campaign can educate the public while aiding in mitigating risk factors, promoting selfefficacy, spotlighting healthy diet and exercise choices, and presenting holistic healing methods to empower individuals, families, and target populations (Giovanelli, et al., 2020; LaMorte, 2016; Simpson, 2015). Behaviorism theory aids in educating the public in making more informed healthy lifestyle choices by changing mindset via facts, options, and advocacy (LaMorte, 2016; Simpson, 2015). Education and empowerment through Behaviorism theory can be translated via multiple media venues, community events, and partnerships (Giovanelli, et al., 2020; LaMorte, 2016; Simpson, 2015).

A public health promotion and education campaign can aid in educating the public regarding COVID-19 health challenges and can assist the public in desiring positive lifestyle behavioral changes using personalized, individualized educational strategies to disseminate new information and knowledge (Giovanelli, et al., 2020; LaMorte, 2016; Simpson, 2015). Instructional best practices and Behavioral theory can be integrated into a public educational media campaign. Furthermore, these practices and instructional approaches can be adapted and infused into the 
national K12 and university school systems (Giovanelli, et al., 2020; LaMorte, 2016; Simpson, 2015). Finally, a media campaign can be developed as an extension for medical practitioners, providers, and clients in those domains.

\section{6-month Timeline for Accomplishing Three COVID-19 Public Health Communication Objectives}

A COVID-19 public health promotion and education campaign is a national agenda and the target audience is the entire U.S. population, individuals with any health issues, health service providers and practitioners, children in K12, individuals in the university system, and individuals in any workplace setting (Saliba \& Barden, 2017; Stanković, Maksimović, \& Osmanović, 2018). Successful public health campaigns involve planning, development, and evaluation. Stakeholder groups and partnerships can be engaged via all levels of identified target populations. Data can be collected and analyzed by utilizing targeted case study groups and survey questionnaires disseminated throughout various channels associated with the populations identified (Creswell, 2008). Qualitative and quantitative methods can be used to analyze the data collected (Creswell, 2008). Evaluation findings and lessons learned can be communicated to stakeholders via multi-media presentations, inperson and electronic meetings, email, internal and external newsletters, and published materials in academic, business, and medical journals.

A SWOT analysis aids in a systematic assessment addressing variables that could possibly affect a public health communications plan (TerzicSupic, Bjegovic-Mikanovic, Vukovic, Santric-Milicevic, Marinkovic, Vasic, \& Laaser, 2015). An assessment below identifies various factors that could influence a national public health promotion and education campaign.

\begin{tabular}{|c|c|}
\hline Strengths & Weaknesses \\
\hline $\begin{array}{l}\text { - Consistent source of growth is current stakeholder base, networks, and } \\
\text { partnerships. } \\
\text { - Organizational, operational, marketing, consulting, educating, and } \\
\text { healthcare knowledge. }\end{array}$ & $\begin{array}{l}\text { - } \quad \text { Funding challenges. } \\
\text { - Possible lack of cooperative participation by } \\
\text { identified target stakeholders. } \\
\text { - Possible rejection of educational benefits in any } \\
\text { of the sectors identified. }\end{array}$ \\
\hline Opportunities & Threats \\
\hline $\begin{array}{l}\text { - Improve communication channels and access with participating } \\
\text { stakeholders. } \\
\text { - Improve access to new stakeholders. } \\
\text { - Improve multimedia presence. } \\
\text { - Cross-partnerships related to health products, services, and providers. } \\
\text { Improved understanding of target population's needs, access to services, } \\
\text { and how to improve these areas. } \\
\text { Individuals are looking for alternative holistic healing medicines and } \\
\text { methods. }\end{array}$ & $\begin{array}{l}\text { - Lack of financials needed for the sectors the plan } \\
\text { needs to penetrate. } \\
\text { Fast rate of technology growth and a need to } \\
\text { remain current and educated regarding tools } \\
\text { available. } \\
\text { - Continuous learning and training cycle for } \\
\text { internal and external stakeholders. }\end{array}$ \\
\hline
\end{tabular}

\section{Figure 1: SWOT Analysis}

Communication objectives (COs) describe details related to the scope and focus of a media campaign's reach, dosage, and changes in the target audience's self-efficacy, beliefs, perceptions, knowledge, and awareness emerging from the campaign's efforts (CDC, 2018). Behavioral objectives (BO) describe what a public health campaign expects individuals to do (CDC, 2018). The scope of behavioral objectives include actions desired emerging from cognitive changes mentioned in corresponding communication objectives (CDC, 2018). Health objectives (HO) describe health indicator changes (CDC, 2018). The scope of health objectives include anticipated outcomes for health emerging from changes in behaviors mentioned in corresponding behavioral objectives (CDC, 2018). Three COs, BOs, and HOs are identified below for a national public health promotion and education campaign plan.

\begin{tabular}{|c|c|c|c|c|c|}
\hline \multicolumn{2}{|c|}{ Communication Objectives (COs) } & \multicolumn{2}{|c|}{ Behavioral Objectives (BO) } & \multicolumn{2}{|c|}{ Health Objectives (HO) } \\
\hline CO1: & $\begin{array}{l}\text { A lack of public } \text { awareness } \\
\text { regarding a holistic healing } \\
\text { perspective } \\
\text { treatment. }\end{array}$ & BO1: & $\begin{array}{l}\text { The public seeks out alternative natural } \\
\text { holistic healing providers, services, } \\
\text { products, methods, and treatments for } \\
\text { healthcare prevention and current health } \\
\text { needs. }\end{array}$ & HO1: & $\begin{array}{l}\text { The public uses alternative } \\
\text { natural holistic healing } \\
\text { providers, services, products, } \\
\text { methods, and treatments for } \\
\text { healthcare prevention and } \\
\text { current health needs. } \\
\text { The public's overall health } \\
\text { and wellness improves. }\end{array}$ \\
\hline CO2: & $\begin{array}{l}\text { An educational need regarding } \\
\text { how the public can be more } \\
\text { proactive in holistic natural } \\
\text { medicine health maintenance. }\end{array}$ & BO2: & $\begin{array}{l}\text { The public becomes proactive in learning } \\
\text { about and educating oneself regarding health } \\
\text { maintenance from a natural holistic } \\
\text { perspective. }\end{array}$ & HO2: & $\begin{array}{l}\text { The public grows in } \\
\text { knowledge regarding health } \\
\text { maintenance from a natural } \\
\text { holistic perspective and } \\
\text { applies the knowledge } \\
\text { through daily lifestyle } \\
\text { changes. }\end{array}$ \\
\hline
\end{tabular}




\begin{tabular}{|c|c|c|c|c|c|}
\hline & & & & & $\begin{array}{l}\text { The public shares new } \\
\text { knowledge with others in } \\
\text { sphere of influence. }\end{array}$ \\
\hline CO3: & $\begin{array}{l}\text { A lack of comprehensive } \\
\text { knowledge regarding how to build } \\
\text { the body's immunity with a } \\
\begin{array}{l}\text { holistic natural medicine } \\
\text { perspective. }\end{array} \\
\begin{array}{l}\text { A lack of comprehensive } \\
\text { knowledge } \\
\text { cardiovascular regarding } \\
\text { cholesterol, blood pressure, diet, } \\
\text { exercise, and how these variables } \\
\text { bear upon poor health conditions. }\end{array}\end{array}$ & BO3: & $\begin{array}{l}\text { The public's desire grows for caring about } \\
\text { more comprehensive knowledge regarding } \\
\text { how to build the body's immunity with a } \\
\text { holistic natural medicine perspective. } \\
\text { The public's desire grows for caring about } \\
\text { more comprehensive knowledge regarding } \\
\text { cardiovascular disease, cholesterol, blood } \\
\text { pressure, diet, exercise, and how these } \\
\text { variables bear upon poor health conditions. }\end{array}$ & HO3: & $\begin{array}{l}\text { The public gains new } \\
\text { comprehensive holistic } \\
\text { healthcare knowledge. } \\
\text { The public applies new } \\
\text { comprehensive holistic } \\
\text { healthcare knowledge } \\
\text { through behavioral health } \\
\text { changes. }\end{array}$ \\
\hline
\end{tabular}

Figure 2: Public Health Campaign Objectives

COMMUNICATION OBJECTIVE 1: A lack of public awareness regarding a holistic healing perspective for COVID-19 treatment.

Related Health Objective(s): The public uses alternative natural holistic healing providers, services, products, methods, and treatments for healthcare prevention and current health needs. The public's overall health and wellness improves.

Related Behavioral Objective(s): The public seeks out alternative natural holistic healing providers, services, products, methods, and treatments for healthcare prevention and current health needs.

Target Audience(s): Entire U.S. population, individuals with any poor health condition, health service providers and practitioners, children in K12, individuals in the university system, and individuals in any workplace setting.

Key Message(s): Seek out alternative natural holistic options and choices.

Figure 3: Objectives, Target Audience, and Key Messages \#1

COMMUNICATION OBJECTIVE 2: An educational need regarding how the public can be more proactive in holistic natural medicine health maintenance.

Related Health Objective(s): The public grows in knowledge regarding health maintenance from a natural holistic perspective and applies the knowledge through daily lifestyle changes. The public shares new knowledge with others in sphere of influence. Related Behavioral Objective(s): The public becomes proactive in learning about and educating oneself regarding health maintenance from a natural holistic perspective.

Target Audience(s): Entire U.S. population, individuals with any poor health condition, health service providers and practitioners, children in K12, individuals in the university system, and individuals in any workplace setting.

Key Message(s): Grow in knowledge regarding alternative natural holistic options and choices.

Figure 4: Objectives, Target Audience, and Key Messages \#2

COMMUNICATION OBJECTIVE 3: A lack of comprehensive knowledge regarding how to build the body's immunity with a holistic natural medicine perspective. A lack of comprehensive knowledge regarding cardiovascular disease, cholesterol, blood pressure, diet, exercise, and how these variables bear upon poor health conditions.

Related Health Objective(s): The public gains new comprehensive holistic healthcare knowledge. The public applies new comprehensive holistic healthcare knowledge through behavioral health changes.

Related Behavioral Objective(s): The public's desire grows for caring about more comprehensive knowledge regarding cardiovascular disease, cholesterol, blood pressure, diet, exercise, and how these variables bear upon poor health conditions.

Target Audience(s): Entire U.S. population, individuals with any poor health conditions, health service providers and practitioners, children in K12, individuals in the university system, and individuals in any workplace setting.

Key Message(s): Apply new knowledge regarding alternative natural holistic options and choices to daily lifestyle.

Figure 5: Objectives, Target Audience, and Key Messages \#3

\begin{tabular}{|l|l|l|c|}
\hline & $\begin{array}{l}\text { Tactics/Channels } \\
\text { /Activities }\end{array}$ & $\begin{array}{l}\text { Staff Responsibilities } \\
\text { Stakeholders Involved }\end{array}$ & Output/Outcomes Measures \\
\hline Months 1-6 & $\begin{array}{l}\text { Tactics } \\
\text { Asses types } \\
\text { communication channels to of }\end{array}$ & $\begin{array}{l}\text { Participating stakeholders and } \\
\text { cooperative partnerships in the } \\
\text { following areas: }\end{array}$ & $\begin{array}{l}\text { Improve the health of } \\
\text { target populations. }\end{array}$ \\
\hline
\end{tabular}




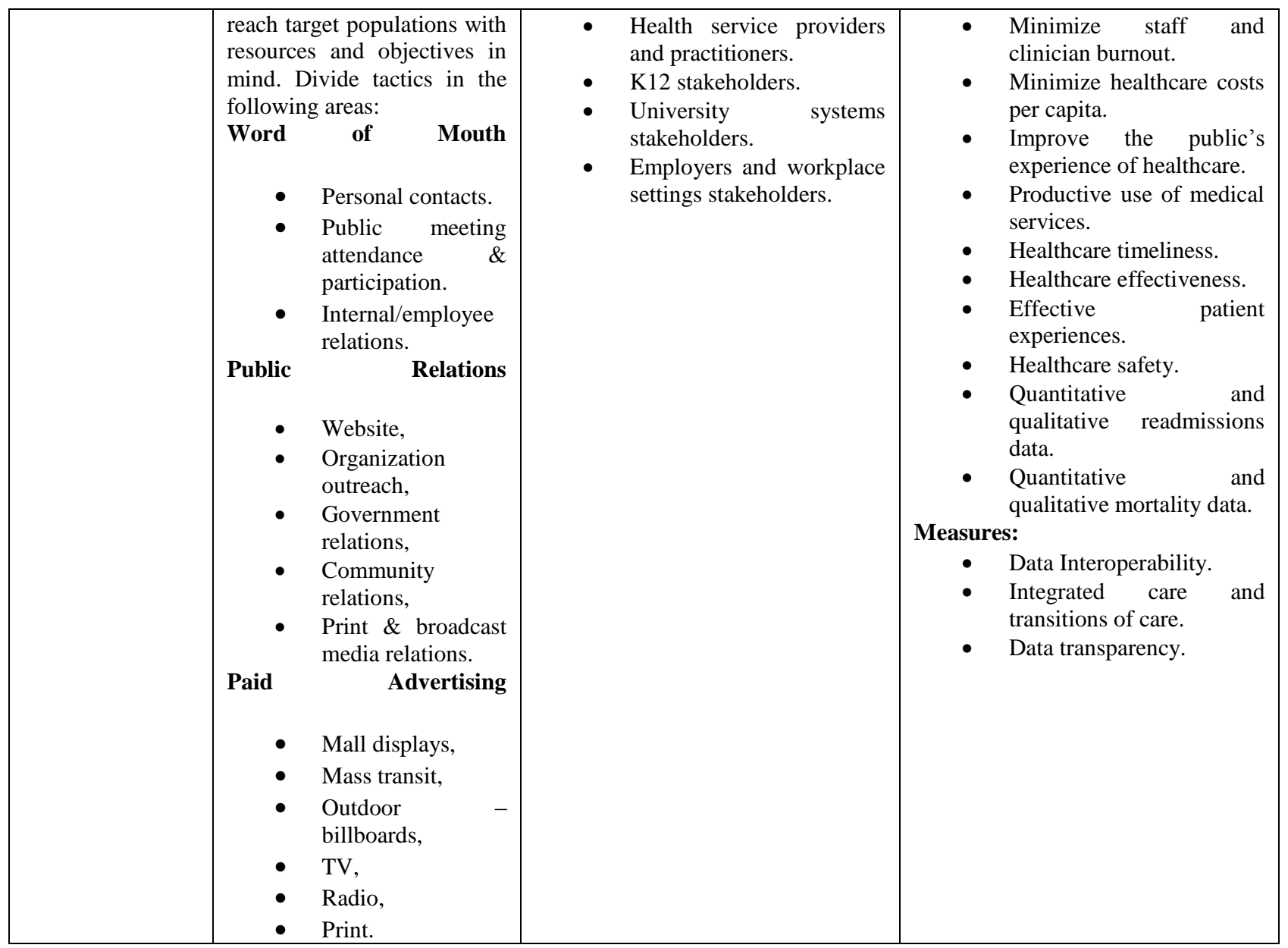

Figure 6: Timeline Tactics, Stakeholders, and Measures

\section{Conclusion}

The article included a COVID-19 public health promotion and education campaign plan to prompt change by applying major behavioral change principles and procedures. Best practices research to motivate, support, and sustain health behavior change included the application of Behavioral Learning Theory when educating the public regarding COVID-19 health challenges. Topics evaluated included: (1) Behavioral Learning Theory, (2) 6-month timeline for accomplishing three COVID-19 public health communication objectives, and (3) SWOT analysis.

\section{References}

1. Centers for Disease Control and Prevention (CDC). (2016). Chronic disease prevention and health promotion.

2. Center for Disease Control and Prevention (CDC). (2018, June 26). NCCDPHP: community health. U.S. Department of Health \& Human Services.

3. Creswell, J. (2008). Research design: Qualitative, quantitative, and mixed methods approaches. Thousand Oaks, CA: Sage Publications.

4. Giovanelli, A., Ozer, E. M., \& Dahl, R. E. (2020, August). Leveraging technology to improve health in adolescence: A developmental science perspective. Journal of Adolescent Health, 67(2), S7-S13.
5. LaMorte, W. W. (2016, Apil 28). Behavioral change models: The transtheoretical model (stages of change). Boston University School of Public Health.

6. Saliba, Y. \& Barden, S. (2017). Counselors and workplace wellness programs: A conceptual model. Professional Counselor, 7(2), 104-113.

7. Simpson, V. (2015, March). Models and theories to support health behavior intervention and program planning. Purdue Extension, Health and Human Services.

8. Stanković, Z., Maksimović, J., \& Osmanović, J. (2018). Cognitive theories and paradigmatic research posts in the function of multimedia teaching and learning. International Journal of Cognitive Research in Science, Engineering and Education, 6(2), 107-114.

9. Terzic-Supic, Z., Bjegovic-Mikanovic, V., Vukovic, D., Santric-Milicevic, M., Marinkovic, J., Vasic, V., \& Laaser, U. (2015, February 26). Training hospital managers for strategic planning and management: A prospective study. BMC Medical Education, 15(25). 